\title{
IN MOMMSEN'S SHADE: ROMAN HISTORIOGRAPHY, PAST AND PRESENT ${ }^{1}$
}

\author{
Mark Humphries
}

\author{
National University of Ireland, Maynooth
}

\section{Roman Empire and German Reich}

When it comes to assessing the reputations of the great modern historians of Roman antiquity, Edward Gibbon (1737-94), in the English speaking world at any rate, perhaps counts for more than Theodor Mommsen (1818-1903). Gibbon's theme is on a grand scale, articulated in mellifluous prose. Mommsen's work cannot compare on either level: the history of the Republic does not evoke the same visceral fascination as the fall of the Empire; and a translation can hardly match the art of an original. Yet as all those who pursue research into the Roman world know, our debt to Mommsen is perhaps greater than that to Gibbon. Whereas Gibbon presented us with a richly painted canvas, Mommsen gave us the pigments and brushes with which to compose our own. A guiding spirit behind such endeavours as the Corpus Inscriptionum Latinarum and the Monumenta Germaniae Historica, Mommsen was instrumental in providing the basic research tools that many of today's Roman historians still use. As an editor of texts and, particularly, inscriptions, Mommsen's knowledge of the raw materials of Roman history was impressive (and we should not forget either his equally detailed knowledge of law and numismatics). But in his History of Rome, his ability to deploy much of that knowledge was restricted. For example, in terms of quantity, most inscriptions pertain to the centuries of the principate; the narrative of Mommsen's History, however, closed with Caesar's victory at Thapsus in $46 \mathrm{BC}$. Whereas some hint of the sophisticated use to which Mommsen could put non-literary material was apparent from that volume of the History devoted to the provinces, it seems always to have been felt that a more fitting arena for their display would have been a study of the Roman world under the emperors. (Indeed, Mommsen himself disparaged the literary sources for the political history of the Empire as "Court tittle-tattle". ${ }^{2}$ ) Throughout the last fifty years of his life, Mommsen was assailed by requests for just such a volume, which many believed would bring the History to a satisfactory conclusion. Between the early-1860s and late1880s he lectured extensively on the topic at Berlin University; but on his death in 1903, only fragmentary writings about the Empire were found among his papers.

That, then, would appear to have been that. Not so, however. In 1980, Alexander Demandt (a distant successor of Mommsen as Professor of Ancient History at Berlin), browsing in a secondhand bookshop in Nuremburg, made an astonishing discovery: a series of bound volumes containing the written-up notes by two students who had attended Mommsen's lectures in 1882-6 on the period between the establishment of the Augustan principate and Alaric's sack of Rome four and a half centuries later. An annotated diplomatic edition of these notes was published in Germany to a rapturous reception in 1992. Now, in Clare Krojzl's elegant translation - together with Demandt's introduction and notes, as well as an essay by the late Thomas Wiedemann setting Mommsen in the historiographical context of nineteenth century Germany - A History of Rome under the Emperors (Mommsen 1996) is available in a form that allows Anglophones an opportunity to see what all the fuss was about.

For many, the publication of such a work may seem to be of only antiquarian interest to those intrigued by the development of a modern academic discipline: who, after all, reads Mommsen's other works these days? ${ }^{3}$ Moreover, new sources continue to appear from the disciplines of 
archaeology, epigraphy, and papyrology. While they do not usually provoke substantial reassessments to our overall interpretation of the major questions of political history, ${ }^{4}$ their greatest contribution has been to open up completely new areas of enquiry, ${ }^{5}$ or offer opportunities for reassessment and refinement. ${ }^{6}$ In the light of these considerations, can a work, based on lectures delivered more than a century ago, possibly be of any use to the modern historian of the Roman Empire?

On reading Mommsen's account, however, one may begin to feel that disparities between the approaches of late-nineteenth and early-twenty first century historians of Roman antiquity are not so great as one might have imagined. By and large, our views of the principate's political history at least in terms of its broad outlines - have not changed much since Mommsen's day. Indeed, in many certain respects Mommsen's approach was surprisingly modern. His decision to push his narrative down to the Gothic sack of Rome in AD 410 put him in advance of his anglophone contemporaries. While the study of the late Roman period has long been in vogue among European scholars, in the English speaking world it was only with pioneering works by A. H. M. Jones (1964) and Peter Brown (1971) that late Roman history entered the mainstream and shook off the stigma of "decline and fall" attached to it by scholars content to accept Gibbon's judgements on the era. ${ }^{7}$

There are other ways in which the general conception of Mommsen's approach to the imperial centuries strikes a chord with modern readers. While political events certainly loom large, they do not dominate (as they do in Gibbon), nor do they always come first. The chapters on the JulioClaudian dynasty, the civil wars of AD 68-69, and Vespasian (together comprising Part I of the book), and the narrative section covering the period from Diocletian to Alaric (Part III of the book), proceed in a straightforward chronological progression. Even so, Mommsen himself was wary of the biographical approach to Roman history, or even periodization according to the reigns of individual emperors. This much is clear from his remarks at the outset of his consideration of the period between Vespasian and Diocletian (Part II of the book): "The beginning of the story of the Emperors may equally well be regarded as the final story of the Roman Republic, in so far as it is not a series of biographies of individual rulers" (Mommsen 1996: 205). Introducing the period from the late-first century to the late-third, he asserted that the "account can no longer proceed chronologically. What I am offering here might more properly be termed 'Observations on the Roman Imperial State" (Mommsen 1996: 205). The chapters that follow are arranged thematically. These begin and end with sections devoted to what are called "Domestic Politics" in the chapter headings, but their range is wider than that rubric might imply. Consideration is given not only to topics like the imperial court, the army, and the senate, but also to regional languages and the economy. Sandwiched in between are a series of chapters whose titles ("Wars in the West", "Wars on the Danube", and "Wars in the East") would appear to promise a relentless account of military affairs. In fact, Mommsen's vision was considerably broader. Much space in these chapters is devoted to a rich and varied picture of society across the Empire, such as an impressive excursus on the provincial civilization of Gaul in among Mommsen's account of wars in the west (Mommsen 1996: 282-95). In sections like this, Mommsen freely dispensed with narrative in favour of the social and cultural history of the Empire's regions. As such his approach has affinities with that adopted in recent studies of the Roman Empire where attention to provincial civilization is deemed crucial to the success of any effort to understand the texture of life in the Roman Empire (e.g. Goodman 1997: 190-284). Throughout such discussions, Mommsen's particular interests are everywhere on display: legal and constitutional questions are thoroughly investigated; social history is elucidated from the inscriptions that Mommsen was in the process of editing while he delivered these lectures; economic history exploits his knowledge of numismatics.

In spite of such virtues, the work is still very much a product of the late-nineteenth century, and the stamp of Mommsen's personality and milieu as well as of his enthusiasms may be found 
everywhere. In the first place, Mommsen did not have access to the same range of resources on which modern scholars routinely depend. For example, Mommsen was composing his lectures just as his collation of the early volumes of the Corpus Inscriptionum Latinarum was beginning to hint at the possibilities that epigraphic evidence might afford the historian. When he remarked of Moguntiacum (Mainz) that "even today the inscriptions and public works still tower above all other finds in these territories [sc. the Rhine frontier] in both number and importance" (Mommsen 1996: 293), there is a hint here that very much more could have been said if only the materials had been properly collected and published. A similar restriction was imposed by the largely urban context of the inscriptions upon which Mommsen's conclusions were based. More intensive research on the ancient countryside, particularly since the end of the Second World War, and the development of sophisticated frameworks within which to interpret such materials have transformed our understanding of rural society in antiquity (Barker 1995: 1-11). Thus, for example, Mommsen's argument that Hellenic Sicily became firmly Latinized (Mommsen 1996: 211-12) contrasts markedly with a recent appraisal that concludes "Sicily never became a fully Romanized province, and some parts, especially the countryside, were hardly affected at all ... Greek continued to be the most widely spoken language, and much of the island remained essentially Greek at heart right to the very end of antiquity" (Wilson 1990: 329, emphasis added). Indeed, the utility of the term "Romanization", which Mommsen uses without hesitation to describe cultural change, has - like "Hellenization" - become the focus of anguished debate among ancient historians and archaeologists in recent years (Curti, Dench, and Patterson 1996; Keay and Terrenato 2001; cf. Whitehouse and Wilkins 1989).

Just as Mommsen was restricted in his presentation by the availability of evidence, so too was he bound by the preconceptions and prejudices of his time and place. Composing at a time when German unity was being forged from a disparate conglomeration of statelets, Mommsen did not see the Roman Empire's network of quasi-autonomous cities, much as recent studies have done, as the "secret of government without bureaucracy" (Garnsey and Saller 1987: 26; cf. Boatwright 2000: 3. 17). On the contrary, Mommsen's judgements on municipal governments were acerbic: "an urban government is narrow-minded, whereas a state has broader horizons" (Mommsen 1996: 216). He was disparaging about the closed world of the cities, as only a patriotic aspirant to German nationhood could be. Surveying the establishment of imperial curatores to oversee municipal affairs, he commented: "this measure was as sensible and beneficial as the abrogation of the status of the Free Imperial Cities, with their short-sighted and narrow-minded parish-pump politics, ultimately proved to be for the German Empire" (Mommsen 1996: 257). Indeed, the spectre of nineteenth century nationalism lurks everywhere. His remark that "language is the crucial vehicle for national integration" (Mommsen 1996: 207) belies a man who grew up at a time when the identification between "nation", "state", and "national language" was becoming ever closer (cf. Hobsbawm 1990: 93-100). One cannot help feeling too that Garibaldi himself would have been proud of the assertion that "the alliance of [Sicily] with its natural mainland of Italy [was] geographically both predestined and justified" (Mommsen 1996: 212).

Moreover, while Mommsen certainly asserted the importance of social and administrative structures, he still subscribed to the view, inherited from antiquity (e.g. Tacitus, Annals 4. 33), that the history of the Roman Empire at a given moment could be driven by the character of the ruling emperor. In such respects, his views of certain emperors seem oddly out of place when compared with more recent assessments. For example, his negative appraisals of Trajan and Hadrian (Mommsen 1996: 338-40) contrast markedly with the positive assessments of both emperors offered by the most recent treatments of them (Bennett 1997; Birley 1997). Indeed, his judgements of character could be as subjective and vicious as anything found in Gibbon's pages. What academic historian today would have the nerve to write of Caligula that he was "pure, unadulterated 
mediocrity, half-crazed and half-witted" (Mommsen 1996: 152), or of Commodus that he was "unspeakably bad: subservient, cowardly, simple-minded and averse to all political activity" (Mommsen 1996: 322)?

Such views would command little assent today, and we can recognise in them the chauvinism and limitations of a nineteenth century academician. It is nonetheless refreshing (and even a delight) to read them and others of their ilk, particularly at a time when some - using insights from sociology or economics - seem to want to squeeze an exact science out of humanistic history (e.g. Duncan-Jones 1982; Hopkins 1978 and 1983). Seen now at a century's distance, Mommsen's verdicts, and the restrictions imposed upon him by his prejudices and access to evidence, are a sobering reminder that what we ourselves write, however persuasive and unbiased it may seem to us, represents little more than a groping after a past that we can never know in all its manifold detail and diversity, and upon which we all impose our preconceptions and personalities, loath though we may be to admit it.

Out of Mommsen's shade: new sources and modern approaches

It would, of course, be inaccurate to assert that, stripped of his nineteenth century prejudices, Mommsen would make a perfectly respectable modern practitioner of Roman history. The last century or so has seen a remarkable transformation in the very way we approach the past. Just how different a view is now taken can be seen by comparing corresponding volumes of the old and the new editions of The Cambridge Ancient History. For example, consider the old and new editions of volume XI, covering that period, from Flavians to the Antonines, usually considered to represent the apogee of the imperial civilization (Cook, Adcock, and Charlesworth 1936; Bowman, Garnsey, and Rathbone 2000). The plan of the first edition shows many affinities with Mommsen in terms of its general conception and scope: there is plenty of political and military narrative, together with analyses of administration and the provinces. By the time we reach the second edition, however, the contents and basic conception of the volume are markedly different. The mentality that, in the first edition, included literature and philosophy alongside politics and war as fitting testimonials of "great men" and their "great works" has given way. In part, the absence of literature has been accomplished by the appearance of a separate Cambridge History devoted to this topic. Yet even where the contents of the old and new editions overlap, striking changes can be observed. The political and military narrative, which had so dominated the first edition, occupies less than a fifth of the new edition. The chapters on the provinces make use of impressive new material garnered from decades of patient archaeological work. But perhaps the most impressive change comes in the form of chapters on topics that were barely mentioned at all in the old edition. Thus the new volume XI boasts studies of "Rebels and outsiders", "The land", "Demography", and "Literacy", to name only a few. The new edition of The Cambridge Ancient History - as a whole, and not just in volume XI - signals the retreat of the former concerns of the ancient historian, such as politics and war, in favour of a new concentration on socio-economic and cultural topics. In so doing, it reflects a new view of priorities well expressed in the succinct polemic of Peter Garnsey in one of his studies of the food supply of the ancient world: "the first concern of the vast majority of the inhabitants of the Mediterranean in ancient times was not whether Alexander the Great would reach the Ocean that surrounded the inhabited world, or whether Julius Caesar was justified in crossing the Rubicon, but food: how to feed themselves and their dependents" (Garnsey 1988: ix).

That Roman historians (indeed, all ancient historians) should take this broader view of what their study involves is in part a result of new types of evidence. The materials yielded by archaeological survey and papyrology, for example, often have little if anything to do with imperial wars and politics, with the affairs of "great men" and their "great works". Such new materials have 
confronted historians with serious methodological problems: precisely how should they be interpreted. In many cases, the response has been to turn to approaches imported from the social sciences, such as comparative ethnography, ${ }^{8}$ or from other historical disciplines. ${ }^{9}$ In many cases, these new approaches and insights have been directed towards areas of traditional concern to the Roman historian, such as the history of provinces (Alcock 1993; Woolf 1998). The trend has also provoked more serious consideration of topics that were previously considered either as marginal or not worthy of detailed, critical analysis. In terms of the Roman past, a key example is provided by the study of religion, a topic barely touched upon in Mommsen's History of Rome under the Emperors. Whereas Roman religion used to be viewed as either something in decline or, worse, merely a means of social control, recent work has reasserted its dynamism (esp. Beard, North, and Price 1998). Thus Roman historians seem to have taken on board the views of the cultural anthropologist Clifford Geertz that rather than being merely an aspect of culture, religion is instead something that is central to culture, providing a key to understanding a culture's conception of the universe in which it exists and the place that a culture occupies in that universe (Geertz 1973: 87125; cf. Price 1984: 7-11). As a result, elements of cult or ritual practice are now integrated with politics and law to provide a more sophisticated understanding of the workings of Roman society (e.g. Beard and Crawford 1985: 25-39; Gargola 1995).

To conclude this survey, I want to look at just one example of these new approaches, where new methodologies and sensitivities have enhanced and transformed our understanding of the Roman world. I take my starting point again from the new edition of volume XI of The Cambridge Ancient History. It is noteworthy that the only plan of a Roman theatre in this volume comes not from the chapters on art and architecture or provincial archaeology, but from that on rebels and outsiders. The purpose of the plan is to show how seating space in the Roman theatre, as "the best venue where the hierarchical order of values could be made manifest", could present a visual image of the "ideal social world" (Shaw 2000: 389). This use of the theatre to demonstrate the structure of the Roman social hierarchy reflects a major change in the deployment of sources and the integration of disciplines used to study the Roman world. Graeco-Roman writing for the stage has long been an object of study for its literary merits. By contrast, investigation of the theatre as a phenomenon embedded in the society that produced it has tended to be a rather marginal field of research. More recently, however, the significance of the theatrical and the spectacular in everyday life in the ancient world has earned a keener appreciation among Roman historians, both of politics and art history. ${ }^{10}$ In particular, spectacle is now recognised as a key element in the articulation of social relations between the Roman élite and its dependants, be they the urban plebs or provincials across the Empire (e.g. Yakobson 1992; Lintott 1993: 175-85). The current fashion for studying the theatrical and spectacular the Roman world should not be misconstrued as some sort of "Gladiatoreffect". It roots are grounded in the proliferation of new approaches to the study of the ancient world. Yet again the impact of anthropological perspectives is apparent: rituals and performance have come to be recognised by social scientists as essential elements in the configuration of any culture (Geertz 1973: 142-69, 412-53).

Recent studies have emphasized the centrality of ritual, spectacle, and theatricality to urban life in the Roman world, and indeed of the ancient world as a whole (Bergmann and Kondoleon 1999). In particular, spectacle has come to be recognized as a key factor in enabling the Roman élite to assert its social and political prominence, such as in the display of images of ancestors at aristocratic funerals (Flower 1996: 91-127) or in the public festivities associated with the triumphal parades of successful generals (Brilliant 1999). The most potent examples of Roman spectacle games in the theatre, amphitheatre, and circus - occupied a central role in political life, making for an intimate relationship between stagecraft and state craft. The phenomenon was given a heightened significance in the last decades of the Republic, when individuals such as Caesar 
sponsored spectacles on a lavish scale in order to affirm their supremacy in political life. In this context, Augustus' management of spectacle shows him to have been, once again, that most adept of late-Republican politicians, whose consummate skill enabled him to transform himself into a monarch (Beacham 1999: 92-154). With the advent of the principate, the provision of spectacles at the city of Rome became the preserve of the emperors. Such games were no more simple acts of generosity now than they had been in the late Republic. That most famous of Roman spectacular venues, the Colosseum, epitomizes the phenomenon. It was begun by Vespasian and dedicated by Titus, the first two emperors of the Flavian dynasty that swept to power in the civil wars of AD 6869. More importantly, it was built on the site of the private gardens of Nero's Golden House. The significance of this transformation was not lost on contemporaries (Martial, Spectacula 1. 2; Suetonius Vespasian 9). Where once the tyrant Nero indulged his private whims, now the new dynasty enchanted the public with spectacles on a scale beyond their wildest expectations. It broadcast the same message as the restoration of the temple of the Deified Claudius, which had been abandoned by Nero, or the omission of Nero's name from the list of imperial precedents cited in the Lex de imperio Vespasiani (CIL 6. 930). As with the triumvirs and Augustus, so with Vespasian and Titus the provision of entertainments helped to secure power and legitimation.

Spectacle, of course, was not simply a case of providing entertainments; they had to provoke a favourable reaction too, as Nero found out to his cost when he publicly persecuted the Christians after the Great Fire of Rome in AD 64 (Tacitus, Annals 15. 44). Recent studies, sensitive to this fact, have sought to bring to light evidence for the interaction between the providers of spectacles and the audiences to which they appealed (Aldrete 1999; Lim 1999). The evidence is scattered and, with the exception of graffiti (Gregori 2001), rarely gives us direct access to the minds of the spectators themselves. But such material is beginning to show Roman historians of other periods something that their colleagues working on late antiquity have known for some time from the evidence of acclamations at Aphrodisias in Caria (Roueché 1984): responses to spectacles, whether in venues for the games or in the street, were often loud and agitated. In turn, these approaches have yielded useful data for the role spectacle played in political life at Rome. Recent work on political oratory at late-Republican and imperial Rome has exploited this research on the mechanics of spectacle in the Roman world. It emphasizes the need to appreciate the visual as well as verbally rhetorical devices employed by orators haranguing the people. Words were important, of course; but so too were the gestures and postures adopted by the speakers, as well as the physical locations in which speeches were delivered (Aldrete 1999; Vasaly 1993). From works such as these comes affirmation that political and social life in the Roman world involved not only the intellect, but also the senses.

In the sophistication of such modern approaches, it is clear that the practice of Roman history has changed considerably since Mommsen delivered his lectures on Rome under the emperors. Material drawn from traditional literary sources is now integrated with data gathered from archaeology, epigraphy, and the art-historical record, and then read in the light of complex methodological frameworks influenced as much by the social sciences as by the traditional tools of classical philology. What Mommsen might have made of these new approaches I dare not hazard to guess. Yet I have the feeling that our image of the Roman world is more vibrantly colourful, and much noisier, than Mommsen's could ever have been. Current research in Roman history is a fertile field, with much being gained by closing the gap between history and archaeology, and using new interpretative frameworks inspired by other intellectual disciplines. If the rediscovery of Mommsen's lost history of the emperors teaches us nothing more than that, then the lesson will have been a salutary one. 
${ }^{1}$ I am grateful to the Editor of Classics Ireland and two anonymous readers for their suggestions about the content and direction of this piece; if I have not always followed their advice, then that has more to do with my stubbornness than anything else, so no-one but the author should be held responsible for the shortcomings of the finished product. My title is a self-conscious nod towards Peter Brown's (1976) "In Gibbon's Shade"” The New York Review of Books 23: 14-18 (repr. in Brown 1982: 49-62).

${ }^{2}$ In conversation with the historian James Bryce in 1898, cited by Demandt in his 'Introduction': Mommsen 1996: 3-4.

${ }^{3}$ One obvious answer is Brian Croke, who has published a number of articles on Mommsen. For a good introduction to Mommsen's working methods see Croke 1993.

${ }^{4}$ A notable exception is a remarkable discovery like the bronze tablets containing the Senatus Consultum de Cn. Pisone patre: see Griffin 1997.

${ }^{5}$ For example, a fine study like Lewis 1983 would have been impossible without the massive industry of papyrologists. Similarly, Noy 2000 shows how epigraphic material can allow for investigations of topics that are largely untouched in literary sources.

${ }^{6}$ Cf. Salway 1981: v-viii on the rapidly changing nature of Romano-British studies in the light of new archaeological work.

${ }^{7}$ Thus the new edition of The Cambridge Ancient History contains two extra volumes - XIII (1998) and XIV (2000) - that pursue the history of the Mediterranean world down to the early seventh century AD, whereas the original edition concluded with Constantine's victory at Chrysopolis in AD 324. Similarly, it was only in its revised edition that The Fontana History of the Ancient World included a volume on late antiquity. The changing circumstances are well-summarized by the author of the late antique volume: "It is a mark of the dramatic change that has taken place in our perceptions of the ancient world that when the new Fontana series was first launched, the later Roman Empire, or, as it is now commonly called, late antiquity, was not included in it; now, by contrast, it would seem strange to leave it out" (Cameron 1993: 1).

${ }^{8}$ Consider, for example, Saller's comparison of Roman patron-client relationships with similar social structures in medieval China (Saller 1982: 111-16).

${ }^{9}$ For the data drawn from archaeological field survey, which can rarely (if ever) show changes in the short term, Annaliste perspectives, particularly those pioneered by Fernand Braudel on gradual change over the longue durée, have proved a useful analytical tool (Bintliff 1991; cf. Barker 1995).

${ }^{10}$ A key study was, of course, Zanker 1988. Recent studies of Roman art history have tended to eschew considerations of 'style' in favour of viewing art as deeply embedded in the culture that produces it: Elsner 1995 and 1998; D'Ambra 1998.

\section{WORKS CITED}

Alcock, S. E. (1993) Graecia Capta. The Landscapes of Roman Greece, Cambridge: Cambridge University Press

Aldrete, G.S. (1999) Gestures and Acclamations in Ancient Rome, Baltimore: The Johns Hopkins University Press

Barker, G (1995) A Mediterranean Valley. Landscape Archaeology and Annales History in the Biferno Valley, London: Leicester University Press

Beacham, R.C. (1999) Spectacle Entertainments of Early Imperial Rome. New Haven: Yale University Press

Beard, M., North, J., and Price, S. (1998) Religions of Rome, Cambridge: Cambridge University Press

Bennett, J. (1997), Trajan: Optimus Princeps, London: Routledge

Bergmann, B. and Kondoleon, C. (eds.) (1999) The Art of Ancient Spectacle, Washington/New Haven: National Gallery of Art/Yale University Press

Bintliff, J. (1991) "The Contribution of an Annaliste/Structural History Approach to Archaeology", in J. Bintliff (ed.) The Annales School and Archaeology, London: Leicester University Press, 1-33

Birley, A. R. (1997) Hadrian: The Restless Emperor, London: Routledge

Boatwright, M.T. (2000) Hadrian and the Cities of the Roman Empire, Princeton, NJ: Princeton University Press

Bowman, A. K., Garnsey, P., and Rathbone, D. (eds.) (2000), The Cambridge Ancient History ${ }^{2}$ XI The High Empire AD 70-192, Cambridge: Cambridge University Press

Brilliant, R. (1999) “'Let the Trumpets Roar!' The Roman Triumph', in Bergmann and Kondoleon 1999: 221-9

Brown, P. (1971) The World of Late Antiquity from Marcus Aurelius to Muhammed, London: Thames and Hudson

Brown, P. (1982) Society and the Holy in Late Antiquity, Berkeley: University of California Press 
Cameron, A. (1993) The Later Roman Empire AD 284-430, London: Fontana

Cook, S. A., Adcock, F. E., and Charlesworth, M. P. (eds.) (1936) The Cambridge Ancient History XI The Imperial Peace AD 70-192, Cambridge: Cambridge University Press

Croke, B. (1993) “Mommsen's Encounter with the Code”, in J. Harries and I. Wood (eds.), The Theodosian Code, London: Duckworth, 217-39

Curti, E., Dench, E., and Patterson, J. (1996) "The Archaeology of Central and Southern Italy: Recent Trends and Approaches", Journal of Roman Studies 86: 170-189

D'Ambra, E. (1998) Art and Identity in the Roman World, London: Everyman

Duncan-Jones, R. P. (1982) The Economy of the Roman Empire: Quantitative Studies ${ }^{2}$, Cambridge: Cambridge University Press

Elsner, J. (1995) Art and the Roman Viewer, Cambridge: Cambridge University Press

Elsner, J. (1998) Imperial Rome and Christian Triumph, Oxford: Oxford University Press

Flower, H. I. (1996) Ancestor Masks and Aristocratic Power in Roman Culture, Oxford: Oxford University Press

Gargola, D. J. (1995) Lands, Laws, and Gods. Magistrates and Ceremony in the Regulation of Public Lands in Republican Rome, Chapell Hill: University of North Carolina Press

Garnsey, P. (1988) Famine and Food Supply in the Graeco-Roman World, Cambridge: Cambridge University Press

Garnsey, P. and Saller, R. (1987) The Roman Empire: Economy, Society, and Culture, London: Duckworth

Geertz, C. (1973) The Interpretation of Cultures. Selected Essays, New York: Basic Books

Goodman, M. (1997) The Roman World 44 BC-AD 180, London: Routledge

Gregori, G. L. (2001) "Aspetti sociali della gladiatura romana”, in A. La Regina (ed.) Sangue e Arena, Milan: Electa, $15-27$

Griffin, M. (1997) “The Senate's Story”, Journal of Roman Studies 87: 249-63

Hobsbawm, E. J. (1990) Nations and Nationalism since 1980. Programme, Myth, Reality, Cambridge: Cambridge University Press

Hopkins, K. (1978) Conquerors and Slaves. Sociological Studies in Roman History I, Cambridge: Cambridge University Press

Hopkins, K. (1983) Death and Renewal. Sociological Studies in Roman History II, Cambridge: Cambridge University Press

Jones, A. H. M. (1964) The Later Roman Empire 284-602. A Social, Economic, and Administrative Survey, Oxford: Blackwell

Keay, S., and Terrenato, N. (eds.) (2001) Italy and the West. Comparative Issues in Romanization, Oxford: Oxbow

Lim, R. (1999) "In the Temple of Laughter': Visual and Literary Representations of the Spectators at Roman Games", in Bergmann and Kondoleon 1999: 343-65.

Lintott, A. (1993) Imperium Romanum. Politics and Administration, London: Routledge

Mommsen, T. (1996) A History of Rome under the Emperors, ed. by B. and A. Demandt; Eng. trans. by C. Krojzl; Eng. ed., with introduction, by T. Wiedemann. London: Routledge

Noy, D. (2000) Foreigners at Rome. Citizens and Strangers, London: Duckworth

Price, S. R. F. (1984) Rituals and Power. The Roman Imperial Cult in Asia Minor, Cambridge: Cambridge University Press

Roueché, C (1984) “Acclamations in the Later Roman Empire: New Evidence from Aphrodisias", Journal of Roman Studies 74: 181-99

Saller, R. P. (1982) Personal Patronage under the Early Empire, Cambridge: Cambridge University Press

Salway, P. (1981) Roman Britain, Oxford: Clarendon Press

Shaw, B. D. (2000) "Rebels and Outsiders" in Bowman, Garnsey, and Rathbone 2000: 361-403

Vasaly, A. (1993) Representations. Images of the World in Ciceronian Oratory, Berkeley: University of California Press

Wilson, R. J. A. (1990) Sicily under the Roman Empire. The Archaeology of a Roman Province 36 BC-AD 535, Warminster: Aris and Phillips

Woolf, G. (1998) Becoming Roman. The Origins of Provincial Civilization in Gaul, Cambridge: Cambridge University Press 
Yakobson, A. (1992) "Petitio et Largitio: Popular Participation in the Centuriate Assembly in the Late Republic", Journal of Roman Studies 82: 32-52

Zanker, P. (1988) The Power of Images in the Age of Augustus, Ann Arbor: University of Michigan Press 